\title{
OPEN SPACE TYPOLOGY OF RESIDENTIAL BUILDINGS IN OTTOMAN CIVILIZATION
}

\author{
Mirna Krpo
}

Original scientific paper

This work primarily aims to cover and analyse the phenomenon of open spaces in residential buildings of Eastern civilization. The function of the high walls in Eastern civilization was a rounding of intimate life of the family and satisfying of the religious customs. The wall not only had a function of a separation, but it had the opposite role, the role of convergence of those who lived behind it, and it also allowed the privacy of the family. Based on the analysis, conclusion was drawn that this was the most authentic open space in the landscape, which was also the bearer of local identity. The results and research of the urban area showed that by the synthesis of the theoretical aspects of the treatment of open space and inspection of all types of premises a conclusion can be drawn that open space, as part of the tradition, goes back much further than the circles of Eastern civilizations, and enters into the sphere of the analysis area during the period of the Roman Empire.

Keywords: city; Eastern civilizations; house; open space; Ottoman period

Tipologija otvorenog prostora stambenih objekata Osmanske civilizacije

Izvorni znanstveni članak Ovaj rad, prvenstveno, ima za cilj da obuhvati i analizira fenomen otvorenog prostora stambenih objekata Istočne civilizacije. Funkcija visokih zidova u Istočnoj civilizaciji predstavljala je zaokruživanje intimnog života obitelji i zadovoljenja vjerskih običaja. Zid nije bio samo u funkciji odvajanja, već je imao suprotnu ulogu, ulogu zbližavanja onih koji stanuju iza njega, a ujedno je omogućavao privatnost obitelji. Na osnovu analiza dolazimo do zaključka da je riječ o najautentičnijem otvorenom prostoru u pejzažu, koji je ujedno i nositelj lokalnog identiteta. Rezultati i istraživanje urbanog prostora su pokazali da sintezom teorijskog aspekta tretiranja otvorenog prostora stambenog objekta, otvoreni prostor predstavlja dio tradicije koji seže mnogo dublje od krugova Istočne civilizacije i ulazi u sferu analize područja u razdoblju Rimskog carstva .

Ključne riječi: grad; Istočna civilizacija; kuća; Osmansko razdoblje; otvoreni prostor

\section{Introduction}

The city is an atmosphere, a formed consciousness, which is based on the feeling of belonging to a certain place and time, while being aware of something hopeful in the future, and mindful of the past. Symbolically speaking, it is a whole world, which in itself wants to achieve a completeness of life [1].

Cities are places in which cultures mature. They are in fact civilizations themselves: In the city, civilizations are born, grown, they realize their historical purposes, degrade, and finally die. A city's culture also shows cases of the civilization's power which separates and differentiates itself from other cultures. On the other hand, a civilization becomes the assumption of the existence of the city itself, the condition of its development [2].

The Orient is an area of ancient civilizations with a long tradition of urbanization, particularly in the GrecoRoman period, from which Islam continued to adapt old cities, and build new ones.

Cities in this region have their functional, social and morphological peculiarities which define a special cultural and genetic city-type which is called the Oriental. The term Oriental has been used by the West as a designation for cultures, people, countries, and goods that belong to the Eastern world, in relation to Europe.

This development was very meaningful, with specific and clearly identifiable characteristics in form and architectural elements, and this specifically related to residential architecture [3].

Mahalas were traditional neighbourhoods found in all parts of the Eastern civilization. They were residential areas with their own mosques, shops, schools, and other facilities needed in daily life. Every mahala had its own communal spirit and mutual-aid system which contributed to the identity of each mahala and to a high degree of social cohesion. This was particularly true of small towns.

Every mahala also had its recognizable differences in term of economical and social state of inhabitants. Those differences were visible in organisation and development of settlements, as well as in organization of house units [4] (Fig. 1).

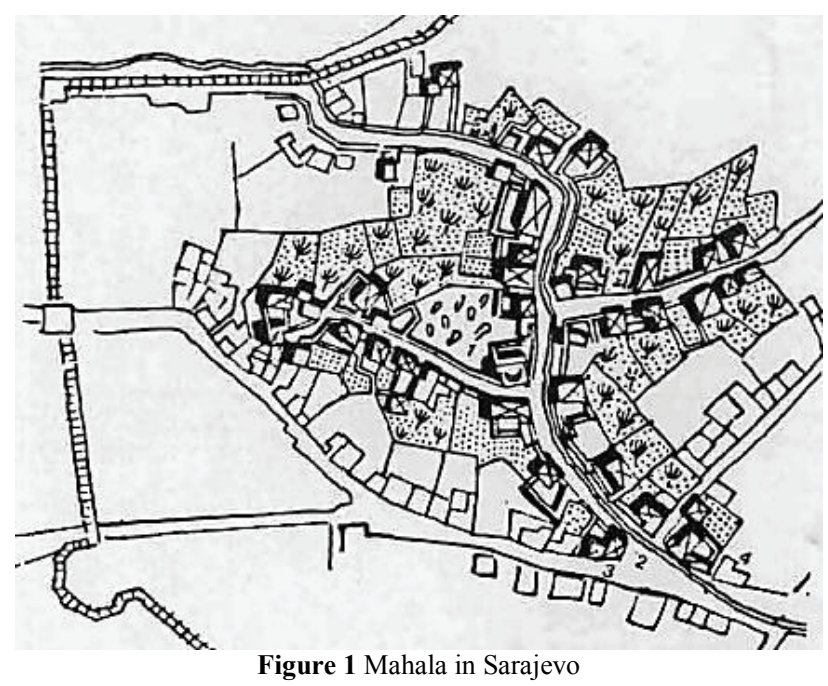

\section{Eastern architecture}

In Eastern architecture, space is never separated from "form": Space is not just the framework in which forms are established, but instead that space is characterized by the forms that are in it [5]. The area is defined in such a way that the space accomplishes integrity and reaches synthesis, at the same time combining different aspects of life. Eastern architecture actually dictates the original multi-functional use of architecturally developed spaces. 
This means that the courtyard walls and arches define the space within the traditional Eastern city and residence, as it is specific feature of the traditional Bosnian house with courtyard. (Figs. 2 and 3).

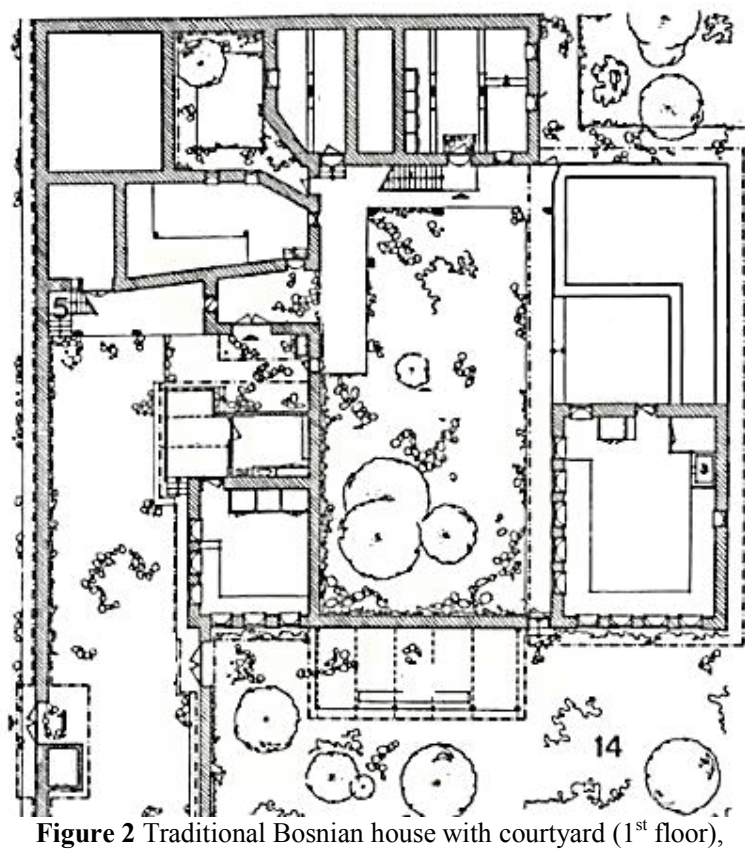

(Svrzo's House, Sarajevo)

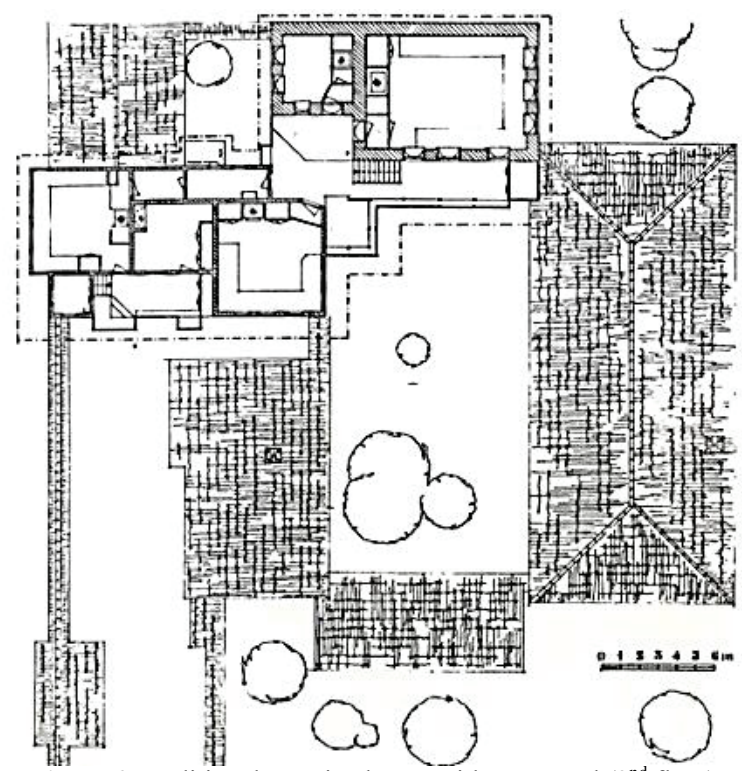

Figure 3 Traditional Bosnian house with courtyard ( $2^{\text {nd }}$ floor $)$, (Svrzo's House, Sarajevo)

Open areas of residential buildings in the examples of contemporary Western European architecture are defined by contours of closed architectural forms and are limited to the central inner position. Unlike Western culture, Eastern architecture in addition to atrial open spaces, is known for its detached open spaces located in the vicinity of residential buildings, which represent a certain boundary between public and private spaces.

Ogrin [6] confirms that this compositional foundation within the Eastern aesthetic is directly derived from religious assumptions about heaven. Within the Eastern creative-drive is found an originally formed scheme which, as a rule, fits within a geometric framework and equally uniform cross-division within that. The landscape is developed totally un-uniform while water is confirmed to be the dominant symbolic and practical feature.

The basic principles of creating open spaces were based on the influence of Islamic art as determined by the principles of the Islamic religion, with that being seen in the relationship between open and closed, built and undeveloped spaces; built spaces and humans connection with nature, and eventually that built space's human scale [7] (Fig. 4).

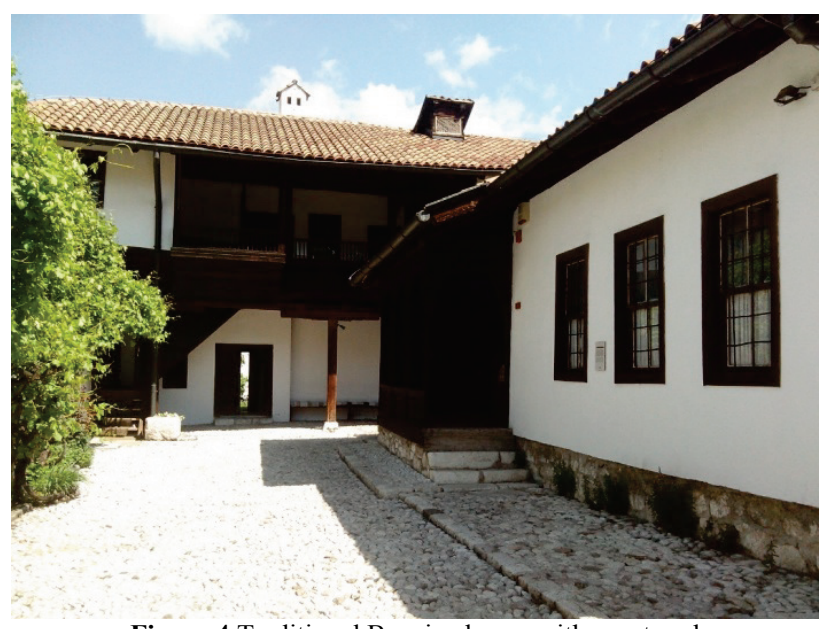

Figure 4 Traditional Bosnian house with courtyard (Svrzo's House, Sarajevo)

In most cases, the beauty of Eastern buildings is primarily the interior orientated focus, instead of a simple connection of interior-exterior, as if thereby suggesting that what actually has an intrinsic value is the inside, not outside, and that there exists a power which shapes and defines the nature of each occurrence [8].

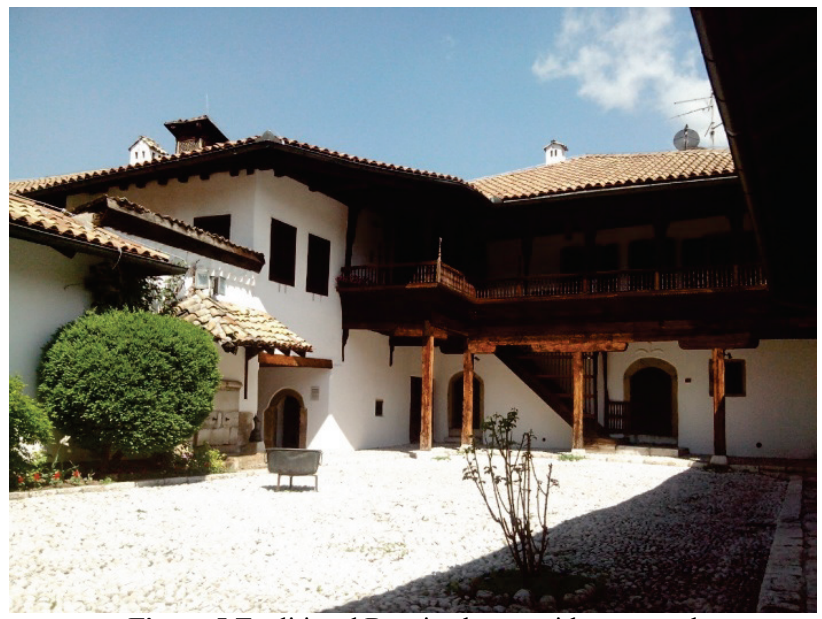

Figure 5 Traditional Bosnian house with courtyard (Svrzo's House, Sarajevo)

Their walls hide an amazing variety of lines and forms, spatial symmetry and grandeur in decorations. This inward-facing architecture is not only responding to a certain city's atmosphere and societal needs, rather it is formed from an outstanding spiritual perspective which is expressing a familiarity with the sublime and beauty (Fig. 5).

The greatest influence on architecture of the Orient was made by the Ottomans who left the largest number of 
beautifully built structures which are recognizable worldwide.

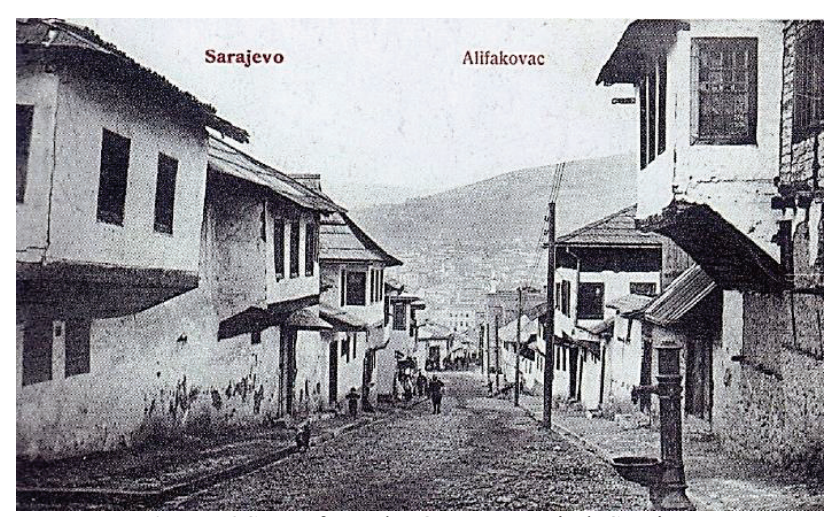

Figure 6 Street from the Ottoman period, Sarajevo

A house was fitted into its natural environment using the local building materials combined with remarkable skill, thus creating a harmonious ensemble. The house was placed horizontally, to follow the contours of surrounding roads, while always respecting the neighbour's right to a pleasant view.

The traditional values of Islam produced intimate spaces, which are traditionally represented by open spaces of residential buildings, as distinct from public open spaces, with the exceptions of the overall function of the street within the urban fabric and places such as sacred spaces and marketplaces.

Each civilization has its own history and its own ancient, middle and modern periods of time. In many cases, these periods are not identical with the old, middle and modern periods of Western culture, which starts with the Greeks. A whole list of cultures preceded Western culture, and some of them indeed developed earlier and are yet, in many ways, still 'contemporary'.

Humanity is made of a series of small and large countries, each of which has its own story, own language, own ideas and passions, unique customs and habits, overarching capabilities and understood goals, a peculiar flow and direction of life. An inseparable part of every urban matrix is the residential unit, which in the Eastern civilization, during the Ottoman period, emerged as a separate zone (Fig. 6). Such residential zones evidence the traditional architectural features of the places they were built in, and thus typically have a striking ambient and character.

\section{Traditional landscape architecture}

Gardens are an integral part of residential culture, while also representing a form of artistic expression. In one aspect, gardens of the East were created under the influence of the religion of Islam and are considered the earthly reflection of paradise. Gardens throughout the Islamic world share similarities by emphasizing the universality of religious art and by making an influence on decorative gardening (Fig. 7). It should be noted that wherever it was possible in the garden, flowing water of streams was utilized [9].

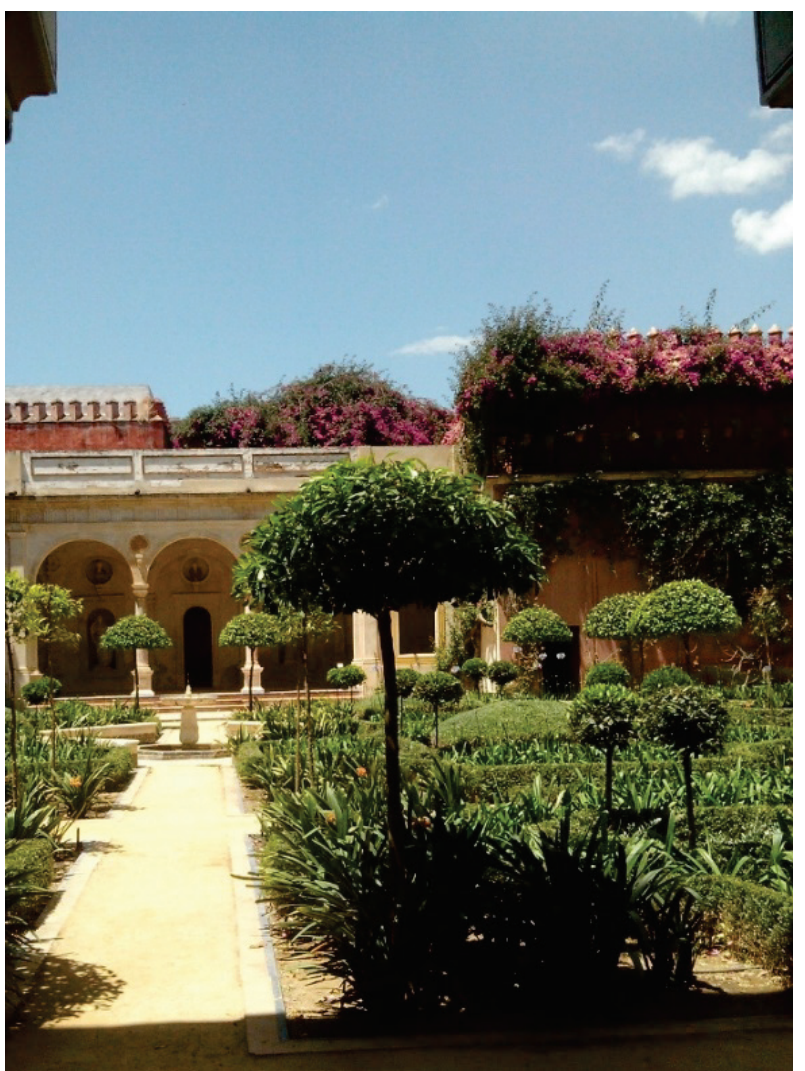

Figure 7 Traditional house in Seville with courtyard from the Ottoman period

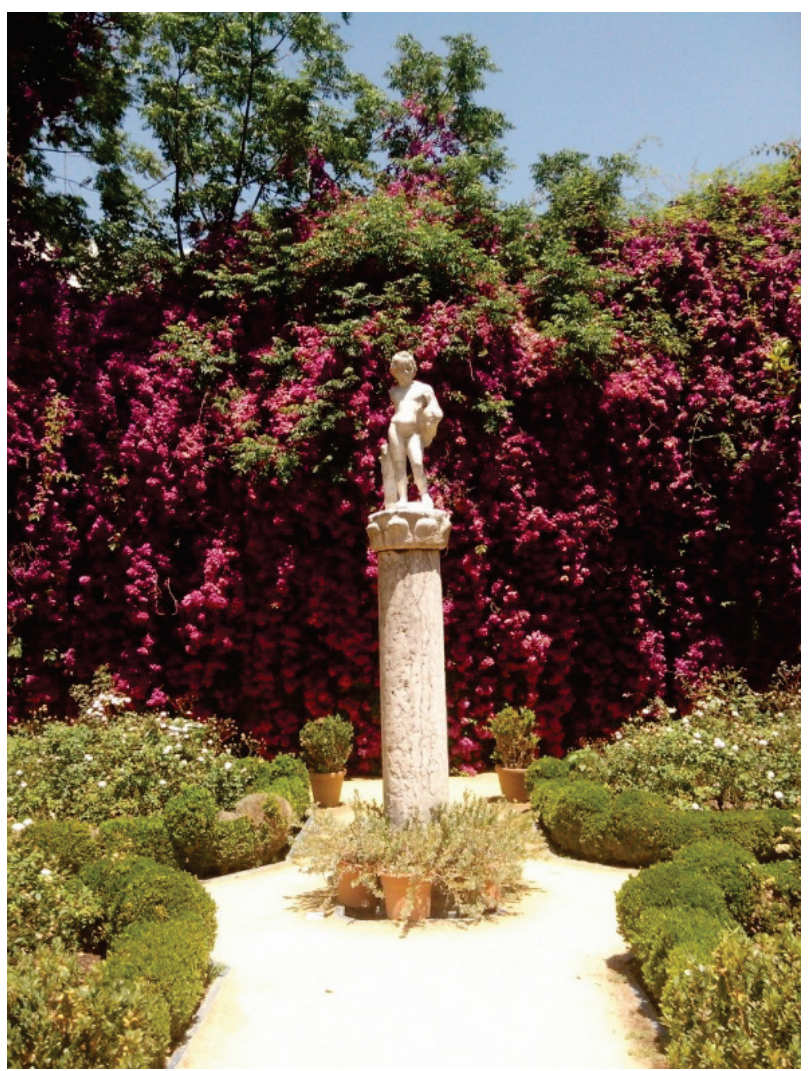

Figure 8 Traditional house in Seville with courtyard from the Ottoman period

The walls flanking the main gate are therefore quite deep, and usually signify the boundaries of a transitional space, while sometimes the gate could simply emphasize entrance into the garden area. Often the gates are on both sides of the open space used as the courtyard garden, 
which is isolated from the street by another open space commonly being used as a commercial yard.

Residential houses fit into the surrounding environment through the necessary use of local, natural materials for construction, alongside the aesthetic and spiritual, warranted Nature's role in architectural composition (Fig. 8).

The traditional house with courtyard is a universal archetype, whose roots derive from the Byzantine culture. In the Eastern civilization, this type of courtyard, as inherited from the Byzantine Empire, also responded to an essentially Muslim necessity for the separation and protection of women. Each civilization has its own framework of cultural expression, different ways of critical thinking, which range from the most casual and individual to maximum organization [10].

Living connected to nature is a Turkish life philosophy with similar lifestyles characterizing a nomadic habit of life. Even after arrival in Anatolia, nomads resisted settling in one place. In accordance with the religion of Islam, the general lifestyle is defined by modesty. Believers are satisfied with very little, people are thrifty and have no desire for luxury, while simplicity is everywhere. Interestingly, this demeanor is evidenced as individuals sit and work on the floor or on low-sitting benches, sleep on beds lying on the floor and eat at low tables.

While not having much furniture in the house, that simplicity also connotes an aesthetic of abundance. Religion held a crucial importance to the disposition and form of the Turkish house.

Religion and traditions closed the residence from the outside. For this reason, the garden and house interior were separated from the street by large walls and the windows were barred. Women would not see men outside the home dynamic and sometimes even inside the house the men and women would live in separate parts, with separate home entrances. This is still characteristic for houses of the rich, while in most homes, there was only one entrance due to financial restrictions.

Overall, there are two types of sections for males and these include pavilions in the garden and male rooms in the home. Some houses have a separated pavilion within the garden area and that structure was composed of one or more spaces. In most cases there was also a pool in the middle of the pavilion with surround seating, and pools were even sometimes built into the male rooms inside the house.

A feature of the upper-class Turkish house is the existence of separate female (haremluk) and male (selamluk) sections. The female part of the house was reached through the door from the courtyard, but there was also direct access to the street. A wall would separate the male and female sections of the courtyard as well, and this would either be a high wall or a movable, wooden and iron construction. The male sections (selamluk) of the important palaces served as the official space to receive a visiting vizier or other important figures and because of that a multitude of governmental functions took place in these open courtyards.

\section{Conclusion}

Islamic religious art is abstract and it combines the flexibility of the line with the emphasis on archetypes. With these basic principles in mind it is understandable why mathematics so strongly influences Muslims; mathematics' abstract nature is a bridge between multiplicity and unity that Muslims were seeking. It provided a fitting symbol for the universe - symbols that were the keys to understanding cosmic text.

Due to the fact that nature creates a certain kind of fear, human nature and its rhythms of life and death were given divine attributes. The harmony between man and nature meant the endeavor of man to submit to nature. The man in modern times, understood as a subject, is defined by the changing of relationship between man and nature. This means that no longer does a man need to be in harmony with nature, but on the contrary, humanity believes in its capability of determining that natural rhythm.

The man is, in the perception of Eastern philosophy, a secondary phenomenon, and in art it is presented as such. In paintings, the landscape is in the foreground, the primary element, while a small human figure is somewhere in the background. The man in the West is in the foreground; seemingly egoistic and focused only on their occurrence. The essential difference between these two philosophies definition of space lies precisely in this respect. The eastern poet sings about the beauty of a flower, about his natural surroundings, and its power to feed and inspire the spirit, while in Western poetry the flower motif is frequently encountered as a decorative detail in the hair of the poet's muse, about whom he sings.

The house is not just a physical structure as we can conclude from this research. It is an extension of the family group; the whole institution which was created to fulfill a number of purposes. In this way the house needs to be seen as the interaction between man and nature. Humanity, nature, lifestyle, worldview, economic opportunities, biological needs, as well as the technical possibilities of the time are built into it.

By analyzing the urban composition from the Ottoman period, it can be concluded that the overall pattern was one of orthogonal streets which were punctuated by public open spaces such as courtyards, mosques and squares. Within this urban matrix, the residential zones are formed as separate surfaces which meet the family's criteria for privacy.

\section{References}

[1] Lynch, K. Slika jednog grada, Građevinska knjiga, Beograd, 1974.

[2] Isanović, N. Razumijevanje Islamske umjetnosti, Islamski pedagoški fakultet u Zenici, El - Kalem Sarajevo, Sarajevo, 2009.

[3] Benevolo, L. Grad u istoriji Evrope, Clio, Beograd, 2004.

[4] Pašić, A. Islamic architecture in Bosnia and Hercegovina, Centre for Islamic History, Art, and Culture, Istanbul, 1994.

[5] Hattstein, M.; Delius, P. Islamska umjetnost i arhitektura, Libris d.o.o, Sarajevo, 2010.

[6] Ogrin, D. Krajinska arhitektura, Oddelek za krajinsko arhitekturo, Biotehniška fakulteta, Univerza v Ljubljani, Ljubljana, 2010. 
[7] Salihović, H. Arhitektura, Stvaralačka sinteza tradicionalno - savremeno, Arhitektonski fakultet, Sarajevo, 2010.

[8] Grabrijan, D. The Bosnian oriental architecture in Sarajevo, Dopisna delavska univerza, DDU Univerzum, Ljubljana, 1984.

[9] Ruggles, F. Islamic gardens and landscapes, University of Pennsylvania Press, Philadelphia, 2007.

[10] Petruccioli, A. Gardens in the time of the great Muslim empires: Theory and Design, Brill Academic Pub, New York, 1997.

\section{Author's address}

Mirna Krpo, mag. arch.

$\mathrm{PhD}$ student of Biotehnical faculty

Department of Landscape architecture

Jamnikarjeva 101

1000 Ljubljana, Slovenia

Tel: +38761272582

E-mail: mirna.krpo.la@gmail.com 